\title{
Cordycepin inhibits TPA-induced matrix metalloproteinase-9 expression by suppressing the MAPK/AP-1 pathway in MCF-7 human breast cancer cells
}

\author{
EUN-MI NOH ${ }^{1 *}$, HYUN JO YOUN ${ }^{2 *}$, SUNG HOO JUNG $^{2}$, JI-HEY HAN ${ }^{1}$, \\ YOUG-JU JEONG ${ }^{3}$, EUN-YONG CHUNG ${ }^{4}$, JI-YOUN JUNG ${ }^{5}$, BYEONG-SOO KIM ${ }^{5}$, \\ SUNG-HO LEE ${ }^{5}$, YOUNG-RAE LEE ${ }^{1}$ and JONG-SUK KIM ${ }^{1}$ \\ Departments of ${ }^{1}$ Biochemistry and Institute for Medical Sciences, ${ }^{2}$ Surgery and \\ ${ }^{3}$ Obstetrics and Gynecology, Chonbuk National University Medical School, Jeonju 560-182; \\ ${ }^{4}$ Department of Anesthesiology and Pain, Catholic University Medical College, Holly Family Hospital, \\ Pucheon 420-818; ${ }^{5}$ Department of Companion and Laboratory Animal Science, \\ Kongju National University, Yesan 340-702, Korea
}

Received September 28, 2009; Accepted November 24, 2009

DOI: $10.3892 /$ ijmm_00000338

\begin{abstract}
Matrix metalloproteinase-9 (MMP-9), which degrades the extracellular matrix (ECM), plays an important role in breast cancer cell invasion. NF- $\mathrm{KB}$ and $\mathrm{AP}-1$ are known to induce MMP-9 expression. We investigated whether cordycepin, an NF- $\mathrm{kB}$ or AP-1 inhibitor, can modulate MMP-9 expression and cell invasion in MCF-7 cells. Toxicity of cordycepin was determined by 3-(4,5-dimethyl-thiazol-2-yl)2,5-diphenyltetrazolium bromide (MTT) assay. MMP-9 expression was determined by real-time PCR, Zymography, and Western blot analysis. AP-1 activation was assayed by electrophoretic mobility shift assay (EMSA). MAPK signaling was evaluated by Western blotting with specific p-ERK, and ERK, p-p38, p38, p-JNK, JNK antibodies. Cordycepin suppressed AP-1 activation, but not $\mathrm{NF}-\mathrm{\kappa B}$ activation in 12-O-tetradecanoylpho-bol-13-acetate (TPA)-treated MCF-7 cells. Cordycepin inhibits TPA-induced MMP-9 expression and cell invasion by suppressing AP-1 activation. Also, cordycepin suppressed the MAPK signaling pathway. Cordycepin is a potent inhibitor of TPA-induced MMP-9 expression and blocks strongly the ability of AP-1 activation via MAPK signaling pathway in MCF-7 cells.
\end{abstract}

Correspondence to: Dr Young-Rae Lee or Dr Jong-Suk Kim, Department of Biochemistry and Institute for Medical Sciences, Chonbuk National University Medical School, Jeonju 560-182, Korea E-mail: mindyr@hanmail.net

E-mail: jsukim@chonbuk.ac.kr

${ }^{*}$ Contributed equally

Key words: cordycepin, matrix metalloproteinase-9, AP-1, MAPK, MCF-7 human breast cancer cells

\section{Introduction}

The Cordyceps mushroom, Cordyceps sinensis, is the most explored species followed by Cordyceps militaris (1-3). Recent studies have shown that extract of Cordyceps exhibits antitumor effects on cancers of the bladder, colon, lung, and fibrosarcoma (4), as well as inhibitory effects on the production of inflammatory mediators (5). Cordyceps and products are available in Western countries as over-the-counter medicine/ tonics that advertise them as Chinese herbs with anti-aging, 'pro-sexual', anti-cancer and immune-boosting effects (3). Cordycepin, which is a 3-deoxyadenosin isolated from Cordyceps, has been reported to exert inhibitory effects on macrophages based on anti-inflammatory properties (6). However, the anti-metastatic effects of cordycepin have not yet been reported.

Invasion and metastasis are the fundamental properties and major causes of morbidity and mortality in breast cancer patients. These processes require degradation of the extracellular matrix (ECM), which provides biochemical and mechanical barriers to cell movement in cancer cells (7). ECM consists of type IV collagen, laminin, heparan sulfate proteoglycan, nidogen and fibronectin (8). ECM degradation requires extracellular proteinases, of which the matrix metalloproteinases (MMPs) have been shown to play a critical role in breast cancer. In recent reports, among the MMP family, gelatinases A (72-kDa gelatinase, type IV collagenase, MMP-2) and B (92-kDa gelatinase, type IV collagenase, MMP-9) play critical roles for ECM degradation and cell migration leading to tumor cell invasion in breast cancer $(8,9)$.

MMPs are a family of zinc- and calcium-dependent endopeptidases, consisting of four subclasses based on substrate, including collagenases, gelatinases, stromelysins and membrane-associated MMPs. MMP-9 was reported to be a key enzyme for degrading type IV collagen, which is a major component of the basement membrane. Elevated MMP-9 levels are functionally linked to elevated metastasis in many tumors, 
including brain (10), prostate (11), bladder (12) and breast $(13,14)$. Several mechanisms regulate MMP-9 activity, including gene transcription, proenzyme activation, and endogenous inhibitors such as tissue inhibitors of metalloproteinases (TIMPs). A variety of stimuli, including cytokines and TPA, can stimulate MMP-9 synthesis and secretion during various pathological processes such as tumor invasion, atherosclerosis, inflammation, and rheumatoid arthritis. MMP-2, on the other hand, is usually expressed constitutively $(14,15)$. Cytokine and TPA treatments can induce MMP-9 expression via activation of transcription factors such as nuclear factor $-\kappa B$ (NF-кB) and activator protein-1 (AP-1) (16-18).

AP-1 is a transcription factor important in the regulation of MMP-9, as the promoter of MMP-9 gene contains binding sites for AP-1 (19). In our previous study, we reported that cordycepin inhibited MMP expressions by suppressing AP-1 activation through the MAPK signaling pathway. Therefore, it was hypothesized that cordycepin has anticancer properties inhibiting cell invasion. In this study, cordycepin was examined for its potential on TPA induced cell invasion and MMP-9 expression in breast carcinoma cells with related molecular mechanisms. Our results demonstrated that cordycepin suppresses TPA-induced MMP-9 expression by blocking the AP-1 activation via the MAPK signaling pathway and the suppression of MMP-9 expression correlates well with its inhibition of cell invasion.

\section{Materials and methods}

Cells and materials. MCF-7 cells were obtained from the American Type Culture Collection (Manassas, VA). Cells were cultured in DMEM supplemented with $10 \%$ fetal bovine serum (FBS) and $1 \%$ antibiotics at $37^{\circ} \mathrm{C}$ in a $5 \% \mathrm{CO}_{2}$ incubator. Cordycepin was purchased from Sigma (St. Louis, MO, USA) and dissolved in dimethyl sulfoxide (DMSO). 12-O-tetradecanoylphorbol-13-acetate (TPA) and 3-(4,5-dimethyl-thiazol2-yl)-2,5-diphenyltetrazolium bromide (MTT), DMSO and anti- $\beta$-actin antibodies were obtained from Sigma (St. Louis, MO, USA). Primary antibodies for p38, p-p38, JNK, p-JNK, ERK, p-ERK were purchased from Cell Signaling Technology (Beverly, MA, USA) and MMP-9 and horseradish peroxidase (HRP)-conjugated IgG were purchased from Santa Cruz Biotechnology (Santa Cruz, CA, USA). High glucosecontaining Dulbecco's modified Eagle's medium (DMEM), FBS and phosphate-buffered saline (PBS) were obtained from Gibco-BRL (Gaithersburg, MD, USA).

Determination of cell viability. The effect of cordycepin on MCF-7 cell viability was determined using an MTT assay. Briefly, cells were seeded to $3 \times 10^{4}$ cells/well and allowed to attach. After $24 \mathrm{~h}$, cells were treated with various cordycepin concentrations $(1,5,10,50$ and $100 \mu \mathrm{M})$. After incubation for $24 \mathrm{~h}$, cells were washed with PBS, MTT $(0.5 \mathrm{mg} / \mathrm{ml} \mathrm{PBS})$ was added to each well and the plates were incubated at $37^{\circ} \mathrm{C}$ for $30 \mathrm{~min}$. Formazan crystals were dissolved with DMSO (100 $\mu \mathrm{l} /$ well) and detected at $570 \mathrm{~nm}$ using a microplate reader (Model 3550, Bio-Rad, Richmond, CA, USA).

Western blot analysis. MCF-7 cells $\left(5 \times 10^{5}\right)$ were pre-treated with cordycepin $(50$ and $100 \mu \mathrm{M})$ for $1 \mathrm{~h}$ and then incubated with TPA for $24 \mathrm{~h}$. Cells were lysed with ice-cold lysis buffer (50 mM Tris- $\mathrm{HCl}, \mathrm{pH} 7.4,1 \% \mathrm{NP}-40,0.5 \%$ sodium deoxycholate, $150 \mathrm{mM} \mathrm{NaCl}, 1 \mathrm{mM}$ EGTA, 0.1\% SDS). The protein concentration in the lysate was determined using the Bradford method (20). Samples (20 $\mu \mathrm{g})$ were separated by SDS-PAGE with $10 \%$ acrylamide, and transferred to Hybond ${ }^{\mathrm{TM}}-\mathrm{PVDF}$ membranes using a Western blot apparatus. The PVDF membranes were blocked with $2 \%$ bovine serum albumin or $5 \%$ skim milk, and then incubated overnight with $1 \mu \mathrm{g} / \mathrm{ml}$ primary antibodies for MMP-9, p38, p-p38, JNK, p-JNK, ERK, p-ERK and $B$-actin. HRP-conjugated $\mathrm{IgG}$ was used as a secondary antibody. Protein expression levels were determined by signal analysis using an image analyzer (Fuji-Film, Japan).

Gelatin zymography assay. Conditioned media were collected after $24 \mathrm{~h}$ stimulation, mixed with non-reducing sample buffer, and electrophoresed in a polyacrylamide gel containing $0.1 \%(\mathrm{w} / \mathrm{v})$ gelatin. The gel was washed at room temperature for 30 min with $2.5 \%$ Triton X-100 solution, and subsequently incubated at $37^{\circ} \mathrm{C}$ for $16 \mathrm{~h}$ in $5 \mathrm{mM} \mathrm{CaCl}_{2}, 0.02 \%$ Brij, and $50 \mathrm{mM}$ Tris- $\mathrm{HCl}$ (pH 7.5). The gel was stained for $30 \mathrm{~min}$ with $0.25 \%(\mathrm{w} / \mathrm{v})$ Coomassie brilliant blue in $40 \%(\mathrm{v} / \mathrm{v})$ methanol/7\% (v/v) acetic acid and photographed on an image analyzer (Fuji-Film, Japan). Proteolysis was imaged as a white zone in a dark blue field. Densitometric analysis was performed using Multi Gauge Image Analysis software (Fuji-Film, Japan).

Quantitative real-time PCR assay. Total RNA was extracted from cells using a FastPure ${ }^{\mathrm{TM}}$ RNA Kit (Takara, Shiga, Japan). The RNA concentration and purity were determined by absorbance at 260/280 nm. cDNA was synthesized from $1 \mu \mathrm{g}$ total RNA using a PrimeScript ${ }^{\mathrm{TM}}$ RT reagent Kit (Takara, Shiga, Japan). MMP-9 and GAPDH mRNA expression were determined by real-time PCR using the ABI PRISM 7900 sequence detection system and SYBR ${ }^{\circledR}$ Green (Applied Biosystems, Foster City, CA, USA). The primers were: MMP-9 (NM 004994) sense, CCTGGAGACCTGAGAACCAATCT; antisense, CCACCCGAGTGTAACCATAGC and GAPDH (NM 002046) sense, ATGGAAATCCCATCACCATCTT; antisense, CGCCCCACTTGATTTTGG. To control for variation in mRNA concentration, all results were normalized to the housekeeping gene, GAPDH. Relative quantitation was performed using the comparative $\Delta \Delta \mathrm{C}_{\mathrm{t}}$ method according to the manufacturer's instructions.

Preparation of nuclear extract. MCF-7 cells $\left(2 \times 10^{6}\right)$ were treated with cordycepin in the presence or absence of TPA for $4 \mathrm{~h}$. Cells were immediately washed twice, scraped into $1.5 \mathrm{ml}$ of ice-cold PBS ( $\mathrm{pH} 7.5$ ), and pelleted at 1,500 x g for $3 \mathrm{~min}$. Cytoplasmic and nuclear extracts were prepared from cells using the NE-PER ${ }^{\circledR}$ Nuclear and Cytoplasmic Extraction Reagents (Pierce Biotechnology, Rockford, IL).

Electrophoretic mobility shift assay (EMSA). Activation of AP-1 and NF-kB was assayed with a gel mobility shift assay using nuclear extracts. An oligonucleotide containing the к-chain ( $\kappa$ B, 5'-CCGGTTAACAGAGGGGGCTTTCCGAG-3') or AP-1 (5'-CGCTTGATGAGTCAGCCGGAA-3') binding site were synthesized and used as a probe for the gel retardation assay. The two complementary strands were 
A<smiles>Nc1ncnc2c1NCN2C1OC(O)CC1O</smiles>

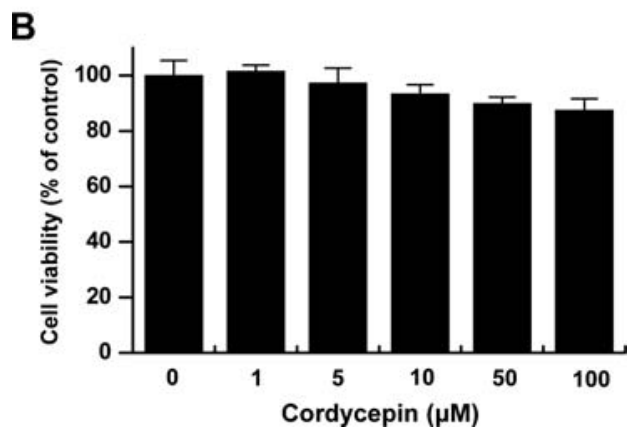

Figure 1. Structure of cordycepin and its effects on MCF-7 viability. The chemical structure of cordycepin (A). To test cytotoxicity of cordycepin, cells were cultured in 96-well plates until $70 \%$ confluence and various concentrations $(1,5,10,50$ and $100 \mu \mathrm{M})$ of codycepin were added to cells for $24 \mathrm{~h}$. Methylthiazoletetrazolium (MTT) assay was used to detect the viability of the cells (B). The optical density value of control was regarded as $100 \%$. Data represent the mean $\pm \mathrm{SEM}$ of three independent experiments.

annealed and labeled with $\left[\alpha^{-32} \mathrm{P}\right] \mathrm{dCTP}$. Labeled oligonucleotides $(10,000 \mathrm{cpm}), 10 \mu \mathrm{g}$ of nuclear extracts, and binding buffer [10 mM Tris-HCl, pH 7.6, $500 \mathrm{mM} \mathrm{KCl,} 10 \mathrm{mM}$ EDTA, 50\% glycerol, $100 \mathrm{ng}$ poly (dI·dC), $1 \mathrm{mM}$ DTT] were then incubated for $30 \mathrm{~min}$ at room temperature in a final volume of $20 \mu 1$. The reaction mixtures were analyzed by electrophoresis on $4 \%$ polyacrylamide gels in $0.5 \mathrm{X}$ Tris-borate buffer. The gels were dried and examined by autoradiography. Specific binding was controlled by competition with a 50 -fold excess of cold $\kappa \mathrm{B}$ or AP-1 oligonucleotide.

Invasion assay. The invasion assay was carried out in 24-well chambers $(8-\mu \mathrm{m}$ pore size) coated with $20 \mu 1$ matrigel diluted DMEM. The matrigel coating was re-hydrated in $0.5 \mathrm{ml}$ DMEM for $30 \mathrm{~min}$ immediately before the experiments. Cells $\left(2 \times 10^{5}\right)$ were added to the upper chamber with chemoattractant in the bottom well. Conditioned medium $(0.5 \mathrm{ml})$ was added to the lower compartment of the invasion chamber. The chambers were incubated for $24 \mathrm{~h}$. After incubation, cells on the upper side of the chamber were removed using cotton swabs, and cells that had migrated were fixed and stained with Toluidine blue solution. Invading cells were counted in five random areas of the membrane using a light microscope. Analyzed data are the means \pm SE from three individual experiments performed in triplicate.
A

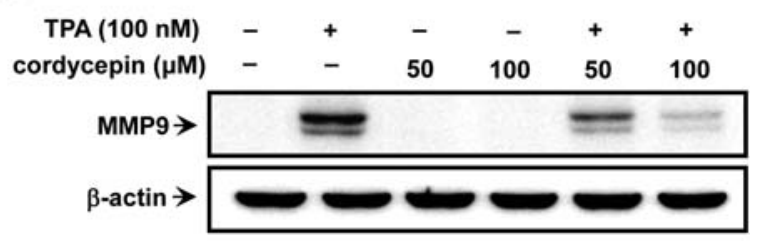

B

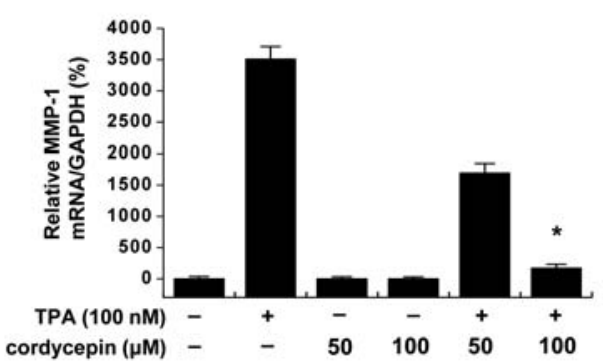

C

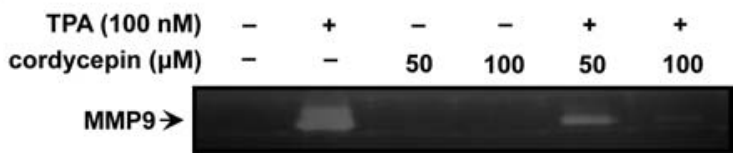

Figure 2. Cordycepin inhibits TPA-induced MMP-9 expression in MCF-7 cells. MCF-7 cells in monolayer were treated with the indicated cordycepin concentrations in the presence of TPA for $24 \mathrm{~h}$. Cell lysates were analyzed by Western blotting with anti-MMP-9. The blot was reprobed with anti-3-actin to confirm equal loading (A). MMP-9 mRNA levels were analyzed by real-time PCR and GAPDH was used as an internal control (B). Conditioned medium was prepared and used for gelatin zymography (C). Each value represents the mean \pm SEM of three independent experiments. ${ }^{*} \mathrm{p}<0.01$ vs. TPA.

Statistical analysis. Statistical data analysis was performed using ANOVA and Duncan's test. Differences with a $\mathrm{p}<0.05$ were considered statistically significant.

\section{Results}

Effect of cordycepin on MCF-7 cell viability. In order to investigate the cytotoxicity of cordycepin (Fig. 1A) on MCF-7 cells, the cells were seeded into 96-well culture plates at a density of $1 \times 10^{5}$ cells/well. Effect of cordycepin on MCF-7 cellular toxicity was analyzed using the MTT assay. Treatment of MCF-7 cells with indicated concentrations of cordycepin for $24 \mathrm{~h}$ did not cause any significant change in cell viability (Fig. 1B). Therefore, we performed experiments in an optimal non-toxic concentration (50 and $100 \mu \mathrm{M})$ of cordycepin with no change in morphology.

Effect of cordycepin on TPA-induced MMP-9 expression in MCF-7 cells. To investigate the effect of cordycepin on TPAinduced MMP-9 expression, we performed Western blot analysis, real-time PCR, and zymography in MCF-7 cells. Western blot analysis revealed that cordycepin treatment of MCF-7 cells blocked the up-regulation of TPA-induced MMP-9 protein expression (Fig. 2A). To determine the effect on TPA-induced MMP-9 secretion by cordycepin, we 


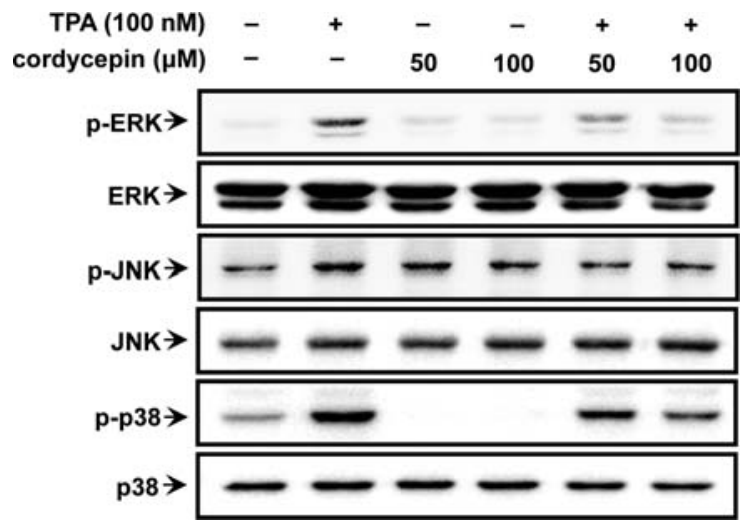

Figure 3. Cordycepin blocks TPA-induced MAPK signaling activation in MCF-7 cells. Cells were pretreated with TPA for $15 \mathrm{~min}$ in the presence or absence of cordycepin. Cell lysates were prepared for Western blotting with specific p-ERK, and ERK, p-p38, p38, p-JNK, JNK antibodies.

A

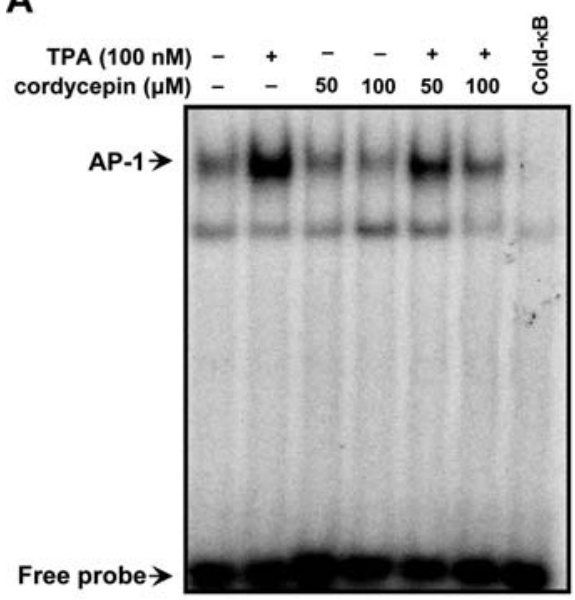

B
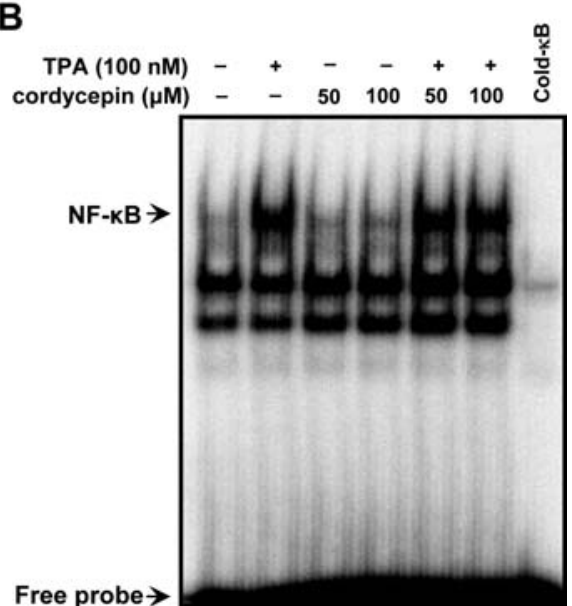

Figure 4. Cordycepin blocks TPA-induced AP-1 activation in MCF-7 cells. Cells were treated with cordycepin in the presence of TPA. Following $3 \mathrm{~h}$ incubation, nuclear extracts were prepared as described in Materials and methods. AP-1 and NF-кB DNA binding was analyzed by electrophoretic mobility shift analysis as described in Materials and methods (B).

performed zymography. MCF-7 cell treatment with TPA resulted in increased MMP-9 secretion. Cordycepin significantly diminished TPA-induced MMP-9 secretion (Fig. 2C). Real-

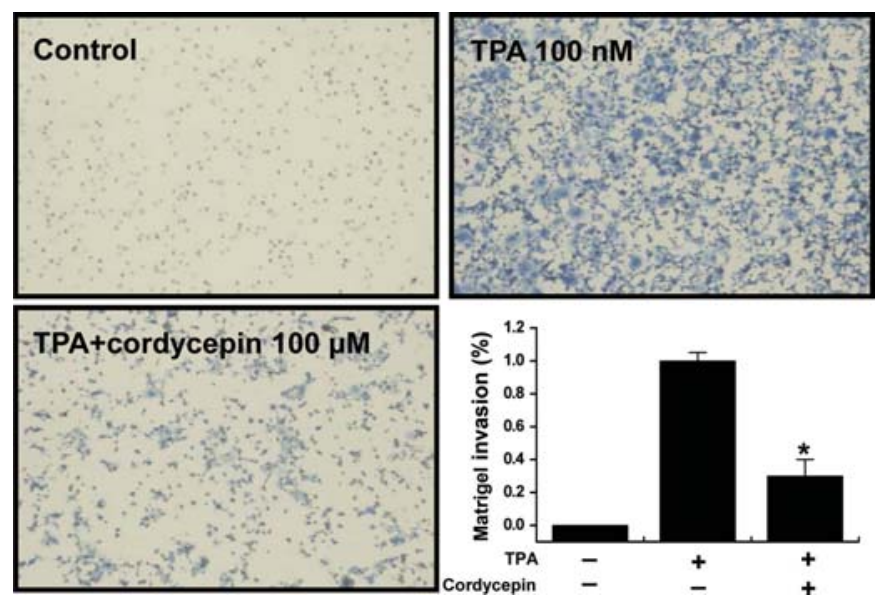

Figure 5. Effect of cordycepin on TPA-induced Matrigel invasion in MCF-7 cells. Cells were seeded onto the upper chamber and drugs were placed in the well. After a $24 \mathrm{~h}$ incubation, cells on the bottom of filter were fixed, stained, and counted. Each value represents the mean \pm SEM of three independent experiments. ${ }^{*} \mathrm{p}<0.01$ vs. TPA.

time PCR revealed that TPA increases MMP-9 level in MCF-7 cells, and that cordycepin blocked TPA-induced MMP-9 upregulation in a dose-dependent manner (Fig. 2B). These results indicate that cordycepin is a potent inhibitor of TPA-induced MMP-9 expression in MCF-7 cells.

Effects of cordycepin on the MAPK signaling pathway by TPA. The upstream regulatory regions of MMP genes contain the AP-1 recognition site. AP-1 can be activated by the MAPK family $(21,22)$. MAPK signaling pathway has been shown to be involved in TPA-induced MMP expression (17). To investigate which MAPK is inhibited, the effect of cordycepin on TPA-induced activation of MAPK was elucidated by using Western blot analysis. As shown in Fig. 3, treatment with TPA significantly enhanced phosphorylation of p38, JNK, and ERK. Treatment with cordycepin blocked TPA-induced phosphorylation of p38, JNK and ERK.

Effect of cordycepin on TPA-induced NF- $\mathrm{KB}$ and AP-1 DNA binding activities. To clarify the mechanism of cordycepinmediated inhibition of MMP-9 expression, the effect of cordycepin on TPA-induced activation of NF- $\kappa \mathrm{B}$ and AP-1 was evaluated using EMSA. As shown in Fig. 4, TPA substantially increased NF-кB and AP-1 binding activity. Treatment with cordycepin inhibited TPA-stimulated AP-1 binding activity but not NF- $\mathrm{KB}$ binding activity. Cordycepin itself had no effect on NF- $\mathrm{NB}$ and AP-1 binding activities. These results suggest that cordycepin specifically blocks AP-1 activation in MCF-7 cells.

Effect of cordycepin on TPA-induced MCF-7 cell invasion in vitro. It has been reported that the up-regulation of MMP-9 expression contributes to invasion of cancer cells $(23,24)$. An in vitro invasion assay was used to investigate the inhibitory effects of cordycepin on the invasive potency of breast carcinoma MCF-7 cells. Treatment of TPA increased MCF-7 cell invasion when compared with untreated control cells, as determined by a Matrigel invasion assay. Incubation of MCF-7 cells with TPA resulted in a 10-fold increase in the invasion 
of MCF-7 cells. However, treatment with cordycepin significantly diminished the TPA-induced cell invasion by $70 \%$ (Fig. 5).

\section{Discussion}

In this study, we have for the first time provided evidence that cordycepin, a bioactive compound found in Cordyceps militaris, inhibits TPA-induced expression of MMP-9 in MCF-7 cells. Our results also showed that cordycepin blocked TPA-mediated activation of AP-1, but not NF- $\mathrm{BB}$, and phosphorylation of ERK, p38 and JNK.

Tumor metastasis is a multistep process by which a subset of individual cancer cells disseminates from a primary tumor to distant secondary organs or tissues. This process involves cell proliferation, ECM degradation, cell migration, and tumor growth at metastatic sites $(14,16)$. Tumor cell invasion is an early step in the metastatic cascade, representing the beginning of the transition from the benign stage to malignancy. Morphologically, tumor invasion is associated with a distorted edge of the primary tumor where individual or cohorts of tumor cells actively invade the tissue ECM surrounding the primary tumor (25).

MMPs have been regarded as major critical molecules in processing tumor invasion and metastasis. MMP-9 activation has been shown to be especially associated with tumor progression and invasion, including mammary tumors (26). In previous reports, inflammatory cytokines, growth factors, or phorbol esters were shown to stimulate MMP-9 by activating different intracellular-signaling pathways in breast cancer cells (27-29). The inhibitory effect of MMP-9 expression is important for the development of a therapeutic experimental model of tumor metastasis.

MAPK pathway is involved in the regulation of cell proliferation, apoptosis, cytokine expression, and MMP production. The three major MAPK families, JNK, ERK, and p38 kinase, are expressed and the active phosphorylated forms can be detected in MCF-7 cells $(14,30)$. In the present study, our results suggest that cordycepin inhibits MAPK activation in TPA-mediated signaling pathways. Supporting our observations, cordycepin inhibits the phosphorylation of MAPK in macrophage cells (31). In our previous study, we reported that cordycepin inhibited MMP-1 and -3 expression by suppressing AP-1 activation through MAPK signaling pathway in rheumatoid arthritis synovial fibroblasts (32). Also, we have confirmed that TPA-induced MMP-9 expression was significantly inhibited by the selective inhibitor of ERK1/2 (PD98059) or JNK (SP600125) and partly inhibited by selective inhibitors of the p38 MAPK (SB203580) (data not shown), and previous studies support our data $(30,33,34)$. These findings suggest that cordycepin inhibits TPA-stimulated MMP-9 expression by suppressing MAPK activation.

AP-1 and NF- $\kappa \mathrm{B}$ are transcription factors important in regulating MMP-9, as the MMP-9 gene promoter contains binding sites for both factors (19). AP-1 is a sequence-specific transcriptional factor composed of Jun, Fos, and ATF family proteins, which is induced by multiple stimuli such as TPA, cytokines, growth factors and stress (35). AP-1, which belongs to the bZIP group of DNA-binding proteins, associates to form a variety of homo- and heterodimers through a combination of signaling events, leading to increased activity of proteins that directly potentiate Jun and Fos family members or activate transcription factors that regulate c-jun and c-fos expression. (18,36-39). NF-кB comprises a family of inducible transcription factors which regulate host inflammatory and immune responses (40). Diverse signal transduction cascades mediate $\mathrm{NF}-\kappa \mathrm{B}$ pathway stimulation (40). NF- $\mathrm{KB}$ is an inducible dimeric transcription factor that belongs to the Rel/NF- $\mathrm{B}$ family of transcription factors and consists of two major polypeptides, p65 and p50 (41). NF- $\mathrm{kB}$ is initially located in the cytoplasm in an inactive form complexed with $\mathrm{I}-\kappa \mathrm{B}$, an inhibitory factor of $\mathrm{NF}-\kappa \mathrm{B}$. Various inducers such as TPA, cytokines and stress can dissociate this complex, presumably

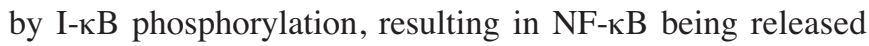
from the complex. NF- $\mathrm{KB}$ then translocates to the nucleus, where it interacts with specific DNA recognition sites to mediate gene transcription. The AP-1 and NF- $\mathrm{BB}$ elements are centrally involved in MMP-9 gene induction by TPA $(16,17)$. Previous studies have shown that the MAPK signaling pathway is important for AP-1 activation, and NF- $\mathrm{KB}$ activation requires I-кB kinase, phosphoinositide 3 kinase (PI3K)-Akt, or p38 MAPK depending on the cell type (42-46). Our results show that cordycepin inhibited MMP-9 expression by suppression of $\mathrm{AP}-1$, but not $\mathrm{NF}-\mathrm{\kappa B}$ in breast carcinoma cells.

In conclusion, our results demonstrate that cordycepin is a potent inhibitor of TPA-induced MMP-9 expression and strongly blocks the ability of MAPK/AP-1 signaling pathway in breast carcinoma cells. This is the first study showing that cordycepin suppresses TPA-stimulated cancer cell invasion by inhibiting MMP-9 expression. We also detail the molecular mechanisms of the MAPK/AP-1 pathway in breast cancer cells responsible for this inhibitory effect. Thus, cordycepin may be a potential candidate for preventing breast tumor invasion and metastasis in vivo.

\section{Acknowledgements}

This work was supported by the National Research Foundation of Korea (NRF) grant funded by the Korea Government (MEST) (No. 2009-0062917), (M10528010003-05N280100310), the Korea Research Foundation Grant (KRF-20090076698), Republic of Korea, and by Korea Breast Cancer Foundation (to Hyun Zo Youn).

\section{References}

1. Cuningham KG, Hutchinson SA, Manson Wand Spring FS: Cordycepin, a metabolic product from culture of Cordyceps militaris (Linn) Link. Part I. Isolation and characterization. J Chem Soc 2: 2299-2302, 1951.

2. Ng TB and Wang HX: Pharmacological actions of Cordyceps, a prized folk medicine. J Pharm Pharmacol 57: 1509-1519, 2005.

3. Paterson RR: Cordyceps: a traditional Chinese medicine and another fungal therapeutic biofactory? Phytochemistry 69: 1469-1495, 2008.

4. Hubbell HR, Requignot EC, Willis DH, Lee C and Suhadolnik RJ: Differential antiproliferactive actions of 2',5' oligo A trimer core and its cordycepin analogue on human tumor cells. Int J Cancer 36: 389-394, 1985.

5. Won SY and Park EH: Anti-inflammatory and related pharmacological activities of cultured mycelia and fruiting bodies of Cordyceps militaris. J Ethnopharmacol 96: 555-561, 2005. 
6. Jeong JG, Kim JM, Cho H, Hahn W, Yu SS and Kim S: Effects of IL-1beta on gene expression in human rheumatoid synovial fibroblasts. Biochem Biophys Res Commun 324: 3-7, 2004.

7. Woessner JF Jr: Matrix metalloproteinases and their inhibitors in connective tissue remodeling. FASEB J 5: 2145-2154, 1991.

8. Nakajima M, Welch DR, Belloni PN and Nicolson GL: Degradation of basement membrane type IV collagen and lung subendothelial matrix by rat mammary adenocarcinoma cell clones of differing metastatic potentials. Cancer Res 47: 4869-4876, 1987.

9. Egeblad M and Werb Z: New functions for the matrix metalloproteinases in cancer progression. Nat Rev Cancer 2: 161-174, 2002.

10. Saito N, Hatori T, Murata N, et al: A double three-step theory of brain metastasis in mice: the role of the pia mater and matrix metalloproteinases. Neuropathol Appl Neurobiol 33: 288-298, 2007.

11. Castellano G, Malaponte G, Mazzarino MC, et al: Activation of the osteopontin/matrix metalloproteinase-9 pathway correlates with prostate cancer progression. Clin Cancer Res 14: 7470-7480, 2008.

12. Kanayama H: Matrix metalloproteinases and bladder cancer. J Med Invest 48: 31-43, 2001

13. Lin CW, Hou WC, Shen SC, et al: Quercetin inhibition of tumor invasion via suppressing PKC delta/ERK/AP-1-dependent matrix metalloproteinase-9 activation in breast carcinoma cells. Carcinogenesis 29: 1807-1815, 2008.

14. Lee SO, Jeong YJ, Kim M, Kim CH and Lee IS: Suppression of PMA-induced tumor cell invasion by capillarisin via the inhibition of NF-kappaB-dependent MMP-9 expression. Biochem Biophys Res Commun 366: 1019-1024, 2008.

15. Nabeshima K, Inoue T, Shimao Y and Sameshima T: Matrix metalloproteinases in tumor invasion: role for cell migration. Pathol Int 52: 255-264, 2002.

16. Chung TW, Moon SK, Chang YC, et al: Novel and therapeutic effect of caffeic acid and caffeic acid phenyl ester on hepatocarcinoma cells: complete regression of hepatoma growth and metastasis by dual mechanism. FASEB J 18: 1670-1681, 2004.

17. Hong S, Park KK, Magae J, et al: Ascochlorin inhibits matrix metalloproteinase- 9 expression by suppressing activator protein-1mediated gene expression through the ERK1/2 signaling pathway: inhibitory effects of ascochlorin on the invasion of renal carcinoma cells. J Biol Chem 280: 25202-25209, 2005.

18. Woo MS, Jung SH, Kim SY, et al: Curcumin suppresses phorbol ester-induced matrix metalloproteinase- 9 expression by inhibiting the PKC to MAPK signaling pathways in human astroglioma cells. Biochem Biophys Res Commun 335: 10171025,2005

19. Eberhardt W, Huwiler A, Beck KF, Walpen S and Pfeilschifter J: Amplification of IL-1 beta-induced matrix metalloproteinase-9 expression by superoxide in rat glomerular mesangial cells is mediated by increased activities of NF-kappa B and activating protein- 1 and involves activation of the mitogen-activated protein kinase pathways. J Immunol 165: 5788-5797, 2000.

20. Bradford MM: A rapid and sensitive method for the quantitation of microgram quantities of protein utilizing the principle of protein-dye binding. Anal Biochem 72: 248-254, 1976

21. Karin M, Liu Z and Zandi E: AP-1 function and regulation. Curr Opin Cell Biol 9: 240-246, 1997.

22. Crawford HC and Matrisian LM: Mechanisms controlling the transcription of matrix metalloproteinase genes in normal and neoplastic cells. Enzyme Protein 49: 20-37, 1996.

23. Chambers AF and Matrisian LM: Changing views of the role of matrix metalloproteinases in metastasis. J Natl Cancer Inst 89: 1260-1270, 1997

24. Stetler-Stevenson WG, Hewitt R and Corcoran M: Matrix metalloproteinases and tumor invasion: from correlation and causality to the clinic. Semin Cancer Biol 7: 147-154, 1996.

25. Deryugina EI and Quigley JP: Matrix metalloproteinases and tumor metastasis. Cancer Metastasis Rev 25: 9-34, 2006

26. Scorilas A, Karameris A, Arnogiannaki N, et al: Overexpression of matrix-metalloproteinase-9 in human breast cancer: a potential favourable indicator in node-negative patients. $\mathrm{Br} \mathrm{J}$ Cancer 84: 1488-1496, 2001.
27. Cho HJ, Kang JH, Kwak JY, et al: Ascofuranone suppresses PMA-mediated matrix metalloproteinase- 9 gene activation through the Ras/Raf/MEK/ERK- and Ap1-dependent mechanisms. Carcinogenesis 28: 1104-1110, 2007.

28. Kajanne R, Miettinen P, Mehlem A, et al: EGF-R regulates MMP function in fibroblasts through MAPK and AP-1 pathways. J Cell Physiol 212: 489-497, 2007.

29. Srivastava AK, Qin X, Wedhas N, et al: Tumor necrosis factoralpha augments matrix metalloproteinase-9 production in skeletal muscle cells through the activation of transforming growth factorbeta-activated kinase 1 (TAK1)-dependent signaling pathway. J Biol Chem 282: 35113-35124, 2007.

30. Lee SO, Jeong YJ, Im HG, Kim CH, Chang YC and Lee IS: Silibinin suppresses PMA-induced MMP-9 expression by blocking the AP-1 activation via MAPK signaling pathways in MCF-7 human breast carcinoma cells. Biochem Biophys Res Commun 354: 165-171, 2007

31. Kumar S, Votta BJ, Rieman DJ, Badger AM, Gowen M and Lee JC: IL-1- and TNF-induced bone resorption is mediated by p38 mitogen activated protein kinase. J Cell Physiol 187: 294-303, 2001

32. Noh EM, Kim JS, Hur H, et al: Cordycepin inhibits IL-1betainduced MMP-1 and MMP-3 expression in rheumatoid arthritis synovial fibroblasts. Rheumatology 48: 45-48, 2009.

33. Simon C, Goepfert H and Boyd D: Inhibition of the p38 mitogenactivated protein kinase by SB 203580 blocks PMA-induced $\mathrm{Mr}$ 92,000 type IV collagenase secretion and in vitro invasion. Cancer Res 58: 1135-1139, 1998.

34. Sun HW, Li CJ, Chen HQ, et al: Involvement of integrins, MAPK, and NF-kappaB in regulation of the shear stress-induced MMP-9 expression in endothelial cells. Biochem Biophys Res Commun 353: 152-158, 2007.

35. Bakiri L, Matsuo K, Wisniewska M, Wagner EF and Yaniv M: Promoter specificity and biological activity of tethered AP-1 dimers. Mol Cell Biol 22: 4952-4964, 2002.

36. Frigo DE, Tang Y, Beckman BS, et al: Mechanism of AP-1mediated gene expression by select organochlorines through the p38 MAPK pathway. Carcinogenesis 25: 249-261, 2004.

37. Shaulian E and Karin M: AP-1 in cell proliferation and survival Oncogene 20: 2390-2400, 2001

38. Yokoo T and Kitamura M: Dual regulation of IL-1 betamediated matrix metalloproteinase-9 expression in mesangial cells by NF-kappa B and AP-1. Am J Physiol 270: F123-F130, 1996.

39. Lungu G, Covaleda L, Mendes O, Martini-Stoica H and Stoica G: FGF-1-induced matrix metalloproteinase- 9 expression in breast cancer cells is mediated by increased activities of NF-kappaB and activating protein-1. Mol Carcinog 47: 424-435, 2008.

40. Yamamoto Y and Gaynor RB: Therapeutic potential of inhibition of the NF-kappaB pathway in the treatment of inflammation and cancer. J Clin Invest 107: 135-142, 2001.

41. Thanos D and Maniatis T: NF-kappa B: a lesson in family values. Cell 80: 529-532, 1995.

42. Yao J, Xiong S, Klos K, et al: Multiple signaling pathways involved in activation of matrix metalloproteinase-9 (MMP-9) by heregulin-beta1 in human breast cancer cells. Oncogene 20: 8066-8074, 2001.

43. Ruhul Amin AR, Senga T, Oo ML, Thant AA and Hamaguchi M: Secretion of matrix metalloproteinase-9 by the proinflammatory cytokine, IL-1beta: a role for the dual signalling pathways, Akt and Erk. Genes Cells 8: 515-523, 2003.

44. Karin M: The regulation of AP- 1 activity by mitogen-activated protein kinases. J Biol Chem 270: 16483-16486, 1995

45. Madrid LV, Mayo MW, Reuther JY and Baldwin AS Jr: Akt stimulates the transactivation potential of the RelA/p65 Subunit of NF-kappa B through utilization of the Ikappa B kinase and activation of the mitogen-activated protein kinase p38. J Biol Chem 276: 18934-18940, 2001.

46. Weng CJ, Chau CF, Hsieh YS, Yang SF and Yen GC: Lucidenic acid inhibits PMA-induced invasion of human hepatoma cells through inactivating MAPK/ERK signal transduction pathway and reducing binding activities of NF-kappaB and AP-1. Carcinogenesis 29: 147-156, 2008. 